38 Beck AT, Steer RA, Ball R, Ranieri W. Comparision of Beck Depression Inventories -IA and -II in psychiatric outpatients. J Pers Assess 1996; 67: 588-97

39 Beck AT, Weissman A, Lester D, Trexler L. The measure of pessimism: the hopelessness scale. J Consult Clin Psychol 1974; 42: 861-5.

40 Beck AT, Epstein N, Brown G, Steer RA. An inventory for measuring clinica anxiety: psychometric properties. J Consult Clin Psychol 1988; 56: 893-7.

41 Barratt ES. Factor analysis of some psychometric measures of impulsiveness and anxiety. Psychol Rep 1965; 16: 547-54.

42 Schwarzer R, Jerusalem M. Generalized self-efficacy scale. In Measures in Health Psychology: A User's Portfolio: Causal and Control Beliefs (eds J Weinman, S Wright, M Johnston): 35-7. nferNelson, 1995.
43 McLeavey BC. Self-poisoning: a study of psychological characteristics and an alternative treatment method. Department of Applied Psychology, University College Cork, doctoral dissertation, 1986.

44 Carter GL, Clover K, Whyte IM, Dawson AH, D'Este C. Postcards from the EDGE project: randomised controlled trial of an intervention using postcards to reduce repetition of hospital treated deliberate self poisoning. BMJ 2005; 331: 805.

45 Foote B, Smolin Y, Neft DI, Lipschitz D. Dissociative disorders and suicidality in psychiatric outpatients. J Nerv Ment Dis 2008; 196: 29-36.

46 Beck AT, Schuyler D, Herman J. Development of suicidal intent scales. In The Prediction of Suicide (eds AT Beck, HLP Resnik, DJ Lettieri): 45-56. Charles Press, 1974

\title{
When a psychiatrist is a patient
}

\section{Aashish Tagore}

I am proud to be a psychiatrist. Despite often feeling stigmatised by medical colleagues, I have always derived a great sense of personal reward and satisfaction from my chosen line of work. As psychiatrists, we try to understand how it must feel for our patients, and we strive to treat them with compassion, empathy and humanity. But what happens when you suddenly find yourself on the other side of the fence?

Last year, after a traumatic event, I started experiencing persecutory delusions and was convinced that my life was in grave danger A descent into full-blown paranoid psychosis ensued, culminating in a hospital admission and treatment with antipsychotic medication.

I was a patient on a ward on which I used to work - my worst nightmare realised. Not only was I embarrassed to be there, the staff with whom I used to work appeared equally embarrassed for me. The pity was written all over their faces. And my own prejudice towards mentally ill patients surfaced. Despite needing acute assessment and treatment, I felt I was for some reason better than or at least different to them. I wanted to distance myself from them - to reassure myself that I was not one of them. But, alas, I was. I was just as unwell, and just as human. I was just as vulnerable and susceptible to mental illness, just as breakable. I was no longer the 'doctor', I was their equal.

After my illness, I felt a sense of deep-seated shame and guilt and came to view myself as 'weak-minded'. This 'self-stigmatisation', where the stigmatised person relates to negative attitudes expressed by others towards themselves and their illness, is debilitating if you share in the negativity surrounding you and view such attitudes as 'understandable', where is the motivation to fight them? Other people's - including my psychiatrist's - wishes to conceal this episode have only served to compound and perpetuate my own sense of shame and embarrassment. Of course, they are concerned about my career. My psychiatrist attempted to minimise the psychotic quality and severity of my illness - does he, too, anticipate discrimination against a fellow doctor with a history of mental illness?

I am relieved to say that currently I am enjoying a period of sustained mental stability, which I can only hope continues ad infinitum. So why did I share my experience of psychotic illness? I surmised that all my anti-stigma support for my patients would not mean a thing unless I was willing to practise as I preach. I would like to think this decision will come to be viewed as one of personal dedication to the cause of de-stigmatising mental illness, and that the whole experience will help me become a better psychiatrist. 